\title{
THE STUDY OF THE USE OF POPULAR NOVELS TO IMPROVE READING INTEREST AND ENGLISH PROFICIENCY
}

\author{
${ }^{1}$ Cynantia Rachmijati; ${ }^{2}$ Anita Anggraeni \\ 1,2Ilmu Keguruan dan Ilmu Pendidikan (IKIP) Siliwangi \\ Corresponding email: cynantiarachmijati@ikipsiliwangi.ac.id
}

\begin{abstract}
The aim of the study is to find out how teachers, parents and students views on popular novels especially KKPK and Teen Lit novels. KKPK and Teen-Lit novels are easily available anywhere and favored by children and adolescents. The topics are interesting to study. The research method is descriptive qualitative. The results show that the novels have many positive impacts. In terms of language, it helps to develop language and vocabulary. In terms of emotions, it helps to develop emotional intelligence. In terms of English, it helps students to learn the structure of sentences and apply them in social media. To increase reading interest, any subject of reading will be better for students while performed it regularly with parents or teachers without any disruption such as gadgets or television.
\end{abstract}

Keywords: KKPK, teen-lit, novels, reading interest, English proficiency

\section{INTRODUCTION}

In the classroom learning process, teachers can not be separated from the book which is used as a source and learning media. Textbooks especially, can accompany teachers in the learning process. Textbooks are a source of learning and media that is very important to support the achievement of competencies that become learning objectives. With a good and fun textbook, it is expected that students' reading ability can improve to be better. Especially when linked in an effort to improve the English language skills of 4 components of language (speaking, listening, reading and writing) is highly recommended that students should read a lot of materials. The goal is to add knowledge, as well as increase the amount of vocabulary they have so that the four components of their language skills can increase.

In addition to textbooks and worksheets that became other sources of learning materials in the classroom, novels can be one additional material in a learning activity. Especially now already recognizable and quite popular are KKPK (Kecil Kecil Punya Karya) and Teen-Lit (Teenager Literature). Both KKPK and Teen-Lit are quite popular for students and teenagers.

Etymologically, teen-lit is an acronym of two English words, "teenager" and "literature". Referring to this understanding, teenlit can be interpreted as a 
segmented reading of adolescents (teenagers) that lifts and covers on adolescent life. Meanwhile, KKPK is a label / series name of a literary publication written by children who were published by Dar! Mizan. KKPK consists of a novel or a collection of short stories around 40 to 45 pages and generally have themes of friendship, fantasy, social and other related stories about children.

As quoted from the page http:/ / www.suara.com, reading interest in Indonesia is still very low. Of the 61 countries surveyed, Indonesia was ranked 60th. To overcome this condition and to more read activity, the Ministry of National Education launched the Indonesian Reading Movement as well as the culture of literacy. Where students are advised to read for 15 minutes a day before the lesson begins.

Teen-lit and KKPK novels which are easily to obtain anywhere and favored by children and adolescents, and contained some English phrases in it interesting to study. Therefore, this study aims to examine the use of KKPK and teen lit novels to increase reading interest and English proficiency among students.

KKPK is a label or series of name published by literary works written by children which are published D a r! Mizan. KKPK was born in December 2003. The first author of KKPK series was Sri Izzati a 8 years old author (Introduction to Publishers in Salsa, 2011). One of the advantages of making KKPK as a literary learning material is that this work is free from pornography because KKPK writers are children. KKPK consists of a novel or a collection of short stories around 40 to 45 pages, size A4 paper, space 1.5, font 12, themes: friendship, fantasy, social and others.

KKPK consists of several types, namely: a) KKPK or Kecil Kecil Punya Karya, b) KKPK or Kecil Kecil Punya Komik, c) KKPK PinkBerry and d) KKPK FantasyTeen

Etymologically, teen lit is an acronym of two English words, 'teenager' and "literature". Referring to this understanding, teenlit can be interpreted as a segmented reading of adolescents (teenagers) that lifts adolescent life. Talking about teen lit certainly cannot be separated from chicklit. The difference between chick-lit and teen lit is ; chicklit directed at the market of woman age of 17-26 years, while teenlit for younger girls , as old as juniorhigh school students (www.suaramerdeka.com). Lately it is not difficult to recognize both, because it always printed "Teenlit" or "Chicklit" on each front cover of the novels.

It appears that the actual form of teenlit writing was already known in Indonesia, even earlier than the United States, only at that time did not have a term to mention it. Genres in popular teen lit are:

1. Chick lit, which tells about the life of young women 
2. Lad Lit is the opposite of chick lit and tells about the life of the male youth. Therefore from the theories proposed above, this research aims to examine the use of KKPK and teen lit novels to increase reading interest and English proficiency among students. And also to find out how teachers, parents and students views on the novels.

\section{METHODS}

Research can be interpreted as an attempt to discover, develop and test the truth of knowledge where efforts are made using scientific methods (Hadi, 2000). This research can be qualitative and quantitative. Qualitative research focuses more on deep understanding of a problem than looking at issues for generalization purposes. Simply, it is stated that the purpose of qualitative research is to understanding the meaning of system which became the general principles of the unit of symptoms contained in the social life of a society. This understanding is obtained through observation, descriptions in a detailed interpretation of the symptoms that are the focus of the study. Therefore it can be concluded that this research is done by using descriptive method with qualitative approach.

\section{Data Collection Technique}

How to collect data is the process of obtaining data from data sources. The data source is the subject of the research in question to obtain the required data. In this research the method used is:

1. Documentation

Documentation in this research is taken from KKPK and Teen-Lit novels

2. Interview

Interview method here is interview with teachers, parents and students as the target readers of KKPK and Teen lit novels

\section{Data Analysis Technique}

In this research, data analysis of interview and documentation is done by qualitative descriptive approach.

\section{FINDINGS}

\section{The Following is an Interview with Teachers, Parents and Students About} KKPK Novels And Teen-Lit

Opinions of parents generally look positive for KKPK novels and teen-lit because it is considered to provide fresh air in addition to textbooks of students which students use daily, the following is the opinion of the parents: 
1. In the past the literature work of children and adolescents is still limited, including: "Lima sekawan" and etc.

2. Novel KKPK for parents is considered to develop the childrens' imagination, improve the skills of Indonesian language and generate interest in reading as well as help to build emotional intelligence of children.

3. Following the times, the most influential in teen-lit development is the entry of Japanese comics or known as "serial cantik".

4. For parents who have children, Mizan's novels such as KKPK, Pink Berry and Fantasteen can be used as one reading option because the story is good, does not lead to pornography elements and there are some English utterance which contains in the novels.

5. In accordance with the soul of a child who has a high level of identification, then the elements of English in the novels teen-lit quickly absorbed by children so that they generally "imitate" in everyday conversations, including writing it in social media.

Teachers also gave a positive view of KKPK's novel and this theme, especially for teachers who teach English that these novels can be used as additional lessons related to the development of vocabulary:

1. For English lessons, an interesting method to start introducing English is with storytelling activities.

2. For students, the books that are usually discussed $90 \%$ are their favorite books are KKPK, PinkBerry and Fantasteen. They like novels that have horror story in it, so they are more happy to read them.

3. The school library is also highly recommended to provide similar novels so as to stimulate students' reading interest and ability.

4. To add a vocabulary to students, English quotations and phrases in the novel can serve as lessons.

5. To increase students' ability in writing, these novels can be used as a reference in addition to the task of writing journals and others.

\section{DISCUSSION}

The students gave a more unique and very specific opinion on why they were interested in reading KKPK and teen-lit novels:

1. The choice and their main consideration in choosing a book to read is a book that has pictures and bright color.

2. The book that becomes an option is a book that is not too thick with a large font size. When it is too thick, no image and small font size usually does not cause the desire to read.

3. Teen Lit novels (especially KKPK) is a favorite for students because the story is interesting, funny and easy to understand. For other 
novel theme genres such as Fantasteen and Pinkberry because the story is more diverse, and contains much elements of horror and mystery. Especially when the story is about school, the students feel more appropriate and in accordance with their daily life.

4. For the element of English, the students learn a lot from the novels. For short words they quite understand, but if long enough then they will learn it by using dictionary. And when they understand, then they will use it in everyday life or write it in social media like Facebook and Instagram.

This study also tries to find reasons why students are not interested in reading, and here are some reasons put forward by them.

1. Reading is boring

Students feel that reading is tedious, plus if they have to divide their time by reading school textbooks and other books, they prefer not to.

2. It has no time and no importance

Students' activities are pretty dense with school activities, courses, extra-curricular and so many others thus they do not have time to read.

3. Reading is difficult

For many students, reading is difficult. Some thought that reading is boring, drowsy, not understanding the sentence and many other reasons.

4. Reading is not fun

To the students especially younger ages, reading activity is not fun. They would prefer to play with friends, watch television or play games instead of having to read a book. Reading is considered to be learning and as a school task, so many feel pressured when reading.

However, many of the benefits of reading are felt by parents and teachers. Among other things is to help expand the vocabulary and introduce many new words. And in KKPK or teen-lit novels, many exemplify how one should behave so as to help students, especially younger ones, to learn to understand the situation and solve problems. And especially, cultivate an interest in reading during the routine and without other distractions, for example gadgets or television.

\section{CONCLUSION AND SUGGESTION}

The views of parents, teachers and students about KKPK novels and teen-lit generally agree that the novel has many positive impacts. In terms of language, help develop new vocabulary and vocabulary. In terms of emotions, help develop emotional intelligence. In terms of English, help students learn the structure of sentences and apply them in social media 
1. For teachers, KKPK novels and teen-lit can be used as one of learning media, especially story-telling.

2. Why students do not like to read, among others, due to the busy activities of students in the school, felt reading as a boring and unimportant activity, as well as unpleasant activities

3. To increase interest in reading, any subject reading will be better for students performed regularly with parents or teachers, without any interference such as gadgets or television.

\section{REFERENCES}

Alwi, Hasan dkk. 2005. Kamus besar Bahasa Indonesia. Jakarta: Balai Pustaka. Anonim.2005. Teen Lit serial ala Sitta Karrina, http:// sembarang.com/2005/09/26/teenlit-serial-ala-sitta-karina/.29 Januari 2016

Annida Online.Alumni KKPK melaju ke lini Pinkberry. (http://annidaonline.com/alumni-kkpk-melaju-ke-lini-baru-pink-berry-club.html)

Anonim.2008.Fenomena Teen Lit.https:/ / houseofreadinc.wordpress.com/2008/06/26/fenomenateenlit/.29 Januari 2016

Anonim.2016.Fenomena buku novel remaja teenlit. http://www.binasyifa.com/279/51/27/ fenomena-buku-novel-remajateenlit.htm.29 Januari 2016

Aziez,Furqonul.2010.Menganalisis fiksi.Bogor:Ghalia Indonesia

Hadi, Sutrisno. 2000.Metodologi Penelitian. Yogyakarta: Andi Yogyakarta

Kurnia,RS.2012.Teen Lit sebagai cermin budaya remaja perkotaan masa kini.http:// pelitaku.sabda.org/teenlit_sebagai_cermin_budaya_remaja_ perkotaan_masa_kini.29 Januari 2016 